\title{
ANALISIS SEGMENTASI PASAR KONSUMEN KOPI HITAM DI KOTA PADANGSIDIMPUAN
}

\section{Oleh:}

\author{
IKHWANUDDIN, Windari, Gende Sahputra \\ Institut Agama Islam Negeri Padangsidimpuan \\ Jl. T. Rizal Nurdin Km.4,5 Kelurahan Sihitang \\ Email: srylestari@yahoo.com
}

\begin{abstract}
Abstrak,
Segmentasi pasar adalah upaya pengelompokan konsumen berdasarkan kebutuhan. Sehingga perusahaan dapat menerapkan pemasaran lebih efektif dan ekonomis. Sebelum diterimanya segmentasi pasar, cara yang umum melakukan bisnis dengan konsumen melalui pemasaran massal yaitu menawarkan produk dan bauran pemasaran yang sama kepada semua konsumen. Berdasarkan wawancara yang peneliti lakukan pada salah satu industri kopi hitam yang beralamat di Kelurahan Hutaimbaru, strategi pemasaran produk masih menggunakan pemasaran massal. Berdasarkan pengamatan peneliti, fenomena di Kota Padangsidimpuan. Kebiasaan masyarakat mengkonsumsi kopi hitam diwarung kopi. Budaya ini hal yang menarik diteliti dalam segmentasi sosial budaya. Permasalahan di atas menjadi rumusan masalah dalam penelitian ini yaitu: bagaimanakah segmentasi pasar konsumen kopi hitam di kota Padangsidimpuan.

Teori-teori yang dibahas dalam penelitian ini sebagai pendekatan terhadap permasalahan yang diteliti adalah teori tentang segmentasi pasar, teoripasar, teori konsumen dan teori perilaku konsumsi dalam persfektif ekonomi konvensional dan ekonomi Islam. Jenis penelitian menggunakan metode kualitatif deskriftif, teknik pengumpulan data menggunakan wawancara. Teknik analisis data menggunakan analisis sebelum di lapangan, analisis data di lapangan model Miles dan Huberman dan analisis data di lapangan model Spradley. Jumlah respon den 6o orang.

Hasil penelitian, berdasarkan segmentasi demografis yaitu konsumen keseluruhan adalah laki-laki, usia>35 tahun, pendidikan secara umum yaitu SMA, pekerjaan secara umumnya wiraswasta, pendapatan rata-rata setiap bulan $\mathrm{Rp}$ 1.000.0000-Rp 2.000.000 dan $>\mathrm{Rp}$ 3.000.0oo. Berdasarkan segmentasi sosial budaya, agama Islam 59 orang, Kristen 1 orang, berdasarkan suku, 55 suku Batak, 2 suku Nias, 3 suku Jawa konsumen suku Batak. Alasan konsumen memilih warung kopi tempat untuk mengkonsumsi kopi hitam untuk berinteraksi sosial dengan masyarakat dan berbagi informasi pekerjaan. Berdasarkan segmentasi terkait pemakaian konsumen tergolong loyal, tingkat pemakaian pemakai ringan 17 orang, pemakai sedang 24 orang, pemakai berat19 orang. Alasan konsumen memilih kopi hitam karena rasa yang khas. Berdasarkan segmentasi psikografis, konsumen menghabiskan waktu dengan, membaca Koran, majalah, menonton acara khusus di TV dan mendengarkan radio. Konsumen berpendapat tidak ada perubahan rasa kopi hitam dari dahulu sampai sekarang. Berdasarkan segmentasi psikologis motivasi awal konsumen mengkonsumsi kopi hitam karena interaksi sosial dengan masyarakat yang terjadi di warung kopi, konsumen suka produk yang berkualitas, suka mencoba produk baru sejenis dan aktif mengikuti perkembangan.
\end{abstract}




\section{Kata kunci :Segmentasi pasar, Konsumen, Pasar dan Perilaku Konsumsi PENDAHULUAN}

Manajemen berdasarkan fungsinya yang pada intinya berusaha untuk mengidentifikasi apa sesungguhnya yang dibutuhkan oleh konsumen dan bagaimana cara pemenuhanya dapat diwujudkan. Untuk dapat mengidentifikasi apa yang dibutuhkan oleh konsumen, maka pebisnis perlu melakukan riset pemasaran, diantaranya berupa survey tentang keinginan konsumen, sehingga pebisnis bisa mendapatkan informasi apa yang sesungguhnya dibutuhkan oleh konsumen. Informasi ini kemudian diteruskan ke bagian produksi untuk dapat diwujudkan. ${ }^{1}$

Konsumen pada dasarnya dikelompokkan ke dalam dua kategori, yakni kategori pertama adalah konsumen individu, atau konsumen perseorangan. Seorang anak sekolah yanga membeli sebuah buku disebuah toko disebut sebagai konsumen individu. Kategori konsumen kedua adalah konsumen institusi, atau konsumen organisasi. ${ }^{2}$ Berdasarkan dari sudut pandang produsen, baik konsumen individu maupun konsumen institusi adalah sama pentingnya, keduanya merupakan penyerap produk barang dan jasa yang ditawarkan pelaku usaha di arena pasar. Tanpa mereka tidak mungkin suatu usaha maju dan berkembang. 3

Industri pengolahan kopi hitam saat ini semakin banyak ditemui terutama di daerah-daerah beriklim dingin, seperti industri-industri pengolahan kopi yang terdapat di daerah Sipirok yang memiliki berbagai macam tanaman kopi.

Pertumbuhan konsumsi lokal di Indonesia di atas 8\% per tahun, Peningkatan didorong menjamurnya warung-warung kopi di beberapa daerah. Produksi kopi Indonesia tahun 2016 sebesar 637.539 ton produksi tersebut menurun dibandingkan dengan produksi pada tahun 2015 sebesar 639.412 ton, sedangkan konsumsi kopi yang terus meningkat di atas 8\% per tahun. ${ }^{4}$ Fenomena konsumsi kopi secara nasional ini tidak jauh berbeda dengan fenomena konsumsi kopi di daerah Kota Padangsidimpuan. Kopi telah

${ }^{1}$ Ernie Tisnawati Sule dan Kurniawan Saefullah, Pengantar Manajemen, (Jakarta: Kencana, 2010), hlm. 14.

${ }^{2}$ Mulyadi Nitisusastro, Perilaku Konsumen, (Bandung: Alfabeta, 2013), hlm. 26.

${ }^{3}$ lbid., hlm. 27.

4 Muhammad Idris, "Digemari Kaum Milenial, Konsumsi Kopi RI Tumbuh 8\% per Tahun" (https://m.detik.com, diakses 28 Juni 2018 pukul 11:42 AM). 
menjadi bagian penting dalam keseharian masyarakat di warung-warung kopi, Namun tidak tersaji seperti trend pengolahan kopi dengan jenis produk yang beraneka ragam.

Perusahaan industri pengolahan kopi yang mendirikan usaha di daerah lain seperti di Kota Padangsidimpuan yang terdapat di Kecamatan Padangsidimpuan Hutaimbaru. Pemilik perusahaan ini adalah bapak M. Yunus Hutasuhut yang berasal dari Sipirok. Industri ini berdiri sejak tahun 2015 dengan jumlah tenaga kerja sebanyak 4 orang. Berdasarkan wawancara yang dilakukan peneliti kegiatan pemasaran produk perusahaan masih menggunakan metode pemasaran massal. 5 Dalam pemasaran massal, penjual menjalankan produksi massal, distribusi massal, dan promosi massal atas produk tertentu bagi semua pembeli, argumen bagi pemasaran massal adalah ia menciptakan potensi pasar yang terbesar, yang akan menghasilkan biaya yang lebih rendah, yang dapat menghasilkan harga yang lebih rendah atau margin lebih tinggi. Namun banyak kritik menunjuk pada kenyataan bahwa pasar itu terpecah-pecah, sehingga pemasaran massal lebih sulit untuk dilaksanakan. Peningkatan jumlah media iklan dan saluran distribusi menyebabkan lebih sulit dan lebih mahal menjangkau khalayak massal. Ada yang mengklaim bahwa pemasaran massal sedang sekarat. Tidak mengejutkan, bahwa banyak perusahaan yang beralih ke pemasaran mikro. ${ }^{6}$

Pemilik menerangkan perusahaan tidak dapat mengidentifikasi jenis konsumen yang menjadi peluang pasar bagi perusahaan, karena dalam manajemen pemasaran produk mereka masih menggunakan metode pemasaran massal. Industri ini mengolah berbagai jenis kopi, seperti kopi Robusta dan Arabika. Mengingat banyaknya produk olahan kopi lain saat ini seperti luwak white coffee, ABC moca, tora bika dan kopi jahe dan produk sejenis lain, hal ini tentunya menjadi persoalan yang penting yang harus disikapi oleh pengusaha industri pengolahan kopi. Variabel yang dapat mempengaruhi konsumsi konsumen adalah usia, budaya, keadaan alam, dan status sosial seseorang dapat mempengaruhi pola konsumsi. Hal ini perlu dikelompok-kelompokan oleh perusahaan dalam segmentasi pasar.7 Studi segmentasi direncanakan untuk mengetahui kebutuhan

${ }^{5}$ Wawancara dengan Bapak M. Yunus Hutasuhut di Industri Pengolhan Kopi dilakukan pada hari Jum'at 21 April 2017.

${ }^{6}$ Philip Kotler dan Kevin Lane Keller, Manajemen Pemasaran. diterjemahkan oleh Benyamin Molan dari “Marketing Management” (Jakarta: PT. Indeks, 2007), hlm. 291.

7Wawancara dengan Bapak M. Yunus dilakukan pada hari Jum'at 21 April 2017 di Industri Pengolahan Kopi Hitam. 
dan keinginan berbagai kelompok konsumen yang spesifik, sehingga barang dan jasa khusus dapat dikembangkan dan ditingkatkan untuk memuaskan kebutuhan setiap kelompok. Berbagai produk baru telah dikembangkan untuk menutup kesenjangan di pasar yang berhasil diungkapkan oleh riset segmentasi. ${ }^{8}$

Berdasarkan pengamatan yang dilakukan peneliti salah satu budaya konsumsi kopi hitam yang tidak biasa yang terdapat di Kota Padangsidimpuan, dalam mengkonsumsi kopi hitam sebagian masyarakat memiliki kebiasaan menikmati kopi hitam di tempat yang biasa disebut warung kopi, budaya ini salah satu hal menarik yang perlu dikaji dan diteliti. Atas dasar latar belakang masalah di atas peneliti tertarik untuk menelitinya dengan bentuk judul. “ANALISIS SEGMENTASI PASAR KONSUMEN KOPI HITAM DI KOTA PADANGSIDIMPUAN. TINJAUAN TEORITIK

\section{Konsumen}

Konsumen dapat diartikan dengan luas disesuaikan dengan tujuan dari konsumen dalam membeli suatu produk. Konsumen berasal dari bahasa Inggris yaitu consumen dan consumer yang arti harfiahnya adalah pembeli. Pengertian lain konsumen adalah pemakai, penikmat, pemakan, pemanfaat, peminum, penerima, pendengar dan pemirsa. 9 Memahami tentang apa dan mengapa konsumen perlu dipelajari tentang berbagai perbedaan dan kesamaan relatif karakteristik yang melekat pada konsumen.

\section{Perilaku Konsumsi}

Wacana perilaku konsumen cukup mendapat perhatian, baik dari kalangan ekonomi konvensional maupun dari kalangan ekonomi Islam. Konsumsi merupakan bagian akhir dari proses produksi. Konsumen yang akan memilih dan menentukan jenis barang dan jasa yang laku di pasar, tanpa konsumen, proses produksi tidak bisa dilanjutkan. ${ }^{10}$

\section{Pasar}

\footnotetext{
${ }^{8}$ Leon G. Schiffman dan Leslie Lazar Kanuk, Op. Cit., hlm. 39.

${ }_{9}^{9}$ Mulyadi Nitisusastro, Perilaku Konsumen, (Bandung: Alfabeta, 2013), hlm. 24.

${ }^{10}$ Muda, Iskandar dan Abdul Nasser Hasibuan, Public Discovery of The Concept of Money with Value of Time Emerald Reach Proceeding Series (Proceeding of MICoMS 2017), Vol 1 pp.255-261
} 
Pasar secara tradisional, "pasar" adalah tempat fisik dimana pembeli dan penjual berkumpul untuk membeli dan menjual barang. Para ahli ekonomi menggambarkan pasar sebagai kumpulan pembeli dan penjual yang melakukan transaksi atas sebuah produk tertentu. Para pemasar sering menggunakan istilah pasar untuk meliput berbagai pengelompokan pelanggan. Pemasar memandang para penjual sebagai pembentuk industri dan pembeli sebagai yang membentuk pasar. ${ }^{11}$

\section{Segmentasi Pasar}

Konsep segmentasi dicetuskan pertama kali oleh Wendell Smith, ditahun 1956, segmentasi adalah upaya mengelompokkan konsumen berdasarkan kebutuhan. Tujuan utamanya adalah mengidentifikasi sekelompok konsumen yang memiliki kebutuhan yang dapat dipenuhi dengan produk tunggal tertentu, sehingga perusahaan dapat menerapkan upaya pemasaran secara lebih efektif dan ekonomis. ${ }^{12}$

\section{METODOLOGI PENELITIAN}

Pendekatan penelitian yang dilakukan peneliti adalah, berdasarkan datanya penelitian ini digolongkan pada penelitian kualitatif yaitu data yang dikumpulkan berbentuk kata-kata atau gambar, bukan angka seperti dalam penelitian kuantitatif. ${ }^{13}$ Berdasarkan metodenya menggunakan penelitian survey, penelitian survey adalah penelitian yang dilakukan pada populasi besar maupun kecil, tetapi data yang dipelajari adalah data dari sampel yang diambil dari populasi tersebut, sehingga ditemukan kejadian-kejadian relatif, distribusi, dan hubungan- hubungan antar variabel sosiologis maupun psikologis. ${ }^{14}$

\section{Unit Analisis/Subjek Penelitian}

Teknik sampling dalam penelitian kualitatif jelas berbeda dengan penelitian nonkualitatif. Pada penelitian nonkualitatif sampel dipilih dari suatu populasi sehingga

${ }^{11}$ Philip Kotler dan Kevin Lane Keller, Manajemen Pemasaran. diterjemahkan oleh Benyamin Molan dari “Marketing Management” (Jakarta: PT Indeks, 2007), hlm. 14.

${ }^{12}$ Fandy Tjiptono, Strategi Pemasaran, (Yogyakarta: Andi Yogyakarta, 2015), hlm.150.

${ }^{13}$ Asmadi Alsa, Pendekatan Kuantitatif \& Kualitatif serta Kombinasinya dalam Penelitian Psikologi, (Celeban Timur: Pustaka Pelajar, 2003), hlm. 40.

${ }^{14}$ Hasibuan, Abdul Nasser, Effects of Auditor Quality on Market-besed and Accounting-based Financial Statement Quality and Its Impacts on Economic Consequences (A Case Indonesian Capital Market), Internasional Journal of Economic Research No.14 (2017). 
dapat digunakan untuk digeneralisasi. Maksud sampling dalam penelitian kualitatif ialah menjaring sebanyak mungkin informasi dari berbagai macam sumber dan bangunanya. Maksud kedua dari sampling dalam penelitian kualitatif adalah menggali informasi yang akan menjadi dasar dari rancangan dan teori yang muncul. Penelitian ini menggunakan konsumen kopi hitam sebagai sumber ataupun subjek penelitian untuk menggali informsai untuk mengetahui segmentasi pasar dari kopi hitam yang ada di Kota Padangsidimpuan. ${ }^{15}$

\section{Teknik Pengolahan dan Analisis Data}

Analisis data adalah proses mengorganisasikan dan mengurutkan data ke dalam pola, kategori, dan satuan uraian dasar sehingga dapat ditemukan tema dan dapat dirumuskan hipotesis kerja seperti yang disarankan oleh data. Analisis data menurut Patton adalah proses mengatur urutan data, mengorganisasikanya ke dalam pola, kategori, dan satuan uraian dasar.

\section{HASIL PENELITIAN}

Pasar terdiri dari pembeli yang berbeda-beda dalam satu hal atau lebih. Perbedaan itu dalam hal keinginan, daya beli, perilaku pembelian dan geografis. Berdasarkan hasil penelitian di atas dapat diketahui bahwa segmentasi pasar kopi hitam di Kota Padangsidimpuan berdasarkan segmentasi demografis, segmentasi sosial budaya, segmentasi terkait pemakaian, segmentasi situasi pemakaian, segmentasi psikografis dan segmentasi psikologis.

1. Segmentasi Demografis

Dalam segmentasi demografis pasar di bagi berdasarkan kelompok usia, jenis kelamin, status perkawinan, pekerjaan dan pendapatan konsumen. Berdasarkan hasil penelitian dan wawancara yang dilakukan peniliti maka yang menjadi kelompok pasar berdasarkan usia adalah dengan usia >35 tahun dengan jenis kelamin keseluruhan laki-laki, pekerjaan konsumen secara umumnya adalah wiraswasta dengan penghasilan paling umum yaitu Rp 1.000.000-Rp 2.000.000 dan > Rp 3.000.000. Tingkat pendidikan rata-rata adalah sampai tingkat SMA. Variabel demografis begitu

${ }^{15}$ Lexy J. Meleong, Metodologi Penelitian Kualitatif, (Bandung: PT Remaja Rosdakarya, 2000), hlm. 165. 
populer bagi pemasar karena variabel ini sering terkait erat dengan kebutuhan dan keinginan konsumen. Alasan lain adalah variabel ini mudah diukur.

Konsumen yang sejatinya adalah penduduk dilihat dari perspektif pelaku usaha yang menjalankan kegiataan kewirausahaan, merupakan bagian terpenting untuk diketahui, dipahami dan diyakini untuk kelancaran pemasaran produk. Dengan kata lain mempelajari seluk-beluk perilaku konsumen merupakan kunci sukses dalam menjalankan usaha.

2. Segmentasi Sosial Budaya

Budaya merupakan karakter masyarakat secara keseluruhan unsur-unsur budaya salah satunya adalah agama, bahasa, suku, dan kebiasaan makan masyarakat. Agama sebagai unsur budaya, dalam agama dan keperacayaan terdapat agama Islam, Kristen, Hindu dan Budha. Hasil penelitian dapat diketahui bahwa konsumen kopi hitam berdasarkan agama secara umumnya adalah orang-orang yang beragama Islam dengan suku terbanyak yaitu dari suku Batak. Budaya dapat mempengaruhi terhadap sikap dan perilaku konsumen.

Penelitian ini mencoba mencari tahu salah satu budaya makan dan minum dari konsumen kopi hitam di Kota Padangsidmpuan. Berdasarkan hasil wawancara dan pengamatan peneliti konsumen memiliki kebiasaan mengkonsumsi kopi hitam di warung kopi alasan konsumen memilih warung kopi karena warung kopi menjadi tempat untuk berinteraksi dengan masyarakat dan berbagi informasi seputar pekerjaan antar masyarakat.

3. Segmentasi Situasi Pemakaian

Segmentasi situasi pemakaian mencoba mengelompokkan konsumen berdasarkan waktu pemakaian produk. Berdasarkan hasil wawancara dan keterangan konsumen kopi hitam, waktu mengkonsumsi kopi hitam secara rutin dilakukan setiap hari dengan pembagian waktu dipagi hari, siang hari, sore hari, malam hari dan pada waktu-waktu senggang. Waktu pemakaian tergolong kuat dan teratur, ini menjadi segmen yang harus dipertahankan oleh pemasar.

4. Segmentasi Terkait Pemakaian

Segmentasi terkait pemakaian mencoba mengelompokkan konsumen berdasarkan status pemakaian, tingkat keloyalan, dan alasan-alasan mengapa 
memilih produk terkait dibanding produk sejenis lain. Hasil penelitian konsumen kopi hitam yang menjadi responden, konsumen tergolong loyal terhadap kopi hitam dengan status pemakaian yang beragam, secara umum pemakai tergolong pemakai sedang dan pemakai berat, keterangan dari konsumen menjelaskan alasan konsumen memilih kopi hitam karena kualitas rasa dan kealamian kopi hitam. Bentuk segmentasi ini sangat populer dalam menggolongkan konsumen dan mengenali tingkat pemakaian produk.

5. Segmentasi Psikografis

Segmentasi psikografis mencoba mengelompokkan konsumen berdasarkan gaya hidup, kegiatan, bagaimana konsumen menghabiskan waktu dan pendapat konsumen tentang berbagai macam kejadian, konsumen kopi hitam di Kota Padangsidimpuan menggunakan waktu dengan berbagai kegiatan seperti, membaca surat kabar, majalah, mendengarkan radio dan menonton acara-acara khusus di TV, hal ini dapat dimanfaatkan pemasar untuk memasarkan produk kopi hitam di surat kabar seperti koran. Kebiasaan konsumen mendengarkan radio juga dapat digunakan pemasar untuk berkomunikasi dengan konsumen secara tidak langsung.

6. Segmentasi Psikologis

Segmentasi psikologis mengelompokkan konsumen berdasarkan motivasi, kepribadian, pengetahuan dan sikap. Berdasarkan hasil wawancara, Konsumen kopi hitam adalah pribadi yang aktif megikuti perkembangan, cenderung suka produkproduk yang berkualitas dan suka mencoba produk-produk baru. Pemasar telah mengembangkan variabel kepribadian untuk mensegmentasikan pasar. Motivasi awal konsumen mengkonsumsi kopi hitam berdasarkan wawancara adalah karena interaksi sosial yang terjadi antar masyarakat di warung kopi. Dorongon lain adalah dorongan yang datang dari teman.

\section{KESIMPULAN}

Berdasarkanuraian pembahasan yang telah dikemukakan dalam bab-bab sebelumnya maka ditarik kesimpulan tentang segmentasi pasar konsumen kopi hitam di Kota Padangsidimpuan sebagai berikut:

Berdasarkan Segmentasi demografis konsumen kopi hitam dikelompokkan Berdasarkan jenis kelamin, pendidikan, pekerjaan dan pendapatan. Konsumen kopi 
hitam lebih banyak dikonsumsi oleh laki-laki dengan usia> 35 tahun, dengan tingkat pendidikan termasuk menengah yaitu SMA, jenis pekerjaan pada umumnya wiraswasta dengan rata-rata pendapatan/bulan $\mathrm{Rp}$ 1.000.000-Rp 2.000.000 dan $>$ Rp 3.000.000.

Berdasarkan Segmentasi sosial budaya dikelompokkan berdasarkan agama, suku, budaya makan dan minum. Berdasarkan agama, konsumen kopi hitam yang beragama Islam 59 orang, Kristen 1 orang. Berdasarkan suku, suku terbanyak yang mengkonsumsi kopi hitam dari suku batak berjumlah 55 orang, suku Jawa 3 orang dan suku Nias 2 orang. Berdasarkan tempat, konsumen biasa mengkonsumsi kopi hitam di warung kopi, sebagai budaya konsumsi masyarakat kota Padangsidimpuan. Alasan konsumen kopi hitam memilih warung kopi sebagai tempat mengkonsumsi kopi hitam karena warung kopi sebagai tempat untuk berinteraksi dengan masyarakat lain dan sebagai tempat berbagi informasi seputar pekerjaan masingmasing konsumen.

Berdasarkan segmentasi situasi pemakaian Konsumen dikelompokkan berdasarkan waktu pemakaian/mengkonsumsi kopi hitam. Berdasarkan waktu, konsumen yang mengkonsumsi kopi hitam pada saat pagi hari berjumlah 3 orang, siang hari 1 orang, sore hari 2 orang, malam hari 3 orang, pagi hari dan malam hari 16 orang, pagi hari dan siang hari 3 orang, pagi hari, siang hari dan malam hari 15 orang, pagi hari, siang hari dan sore hari 2 orang, sedangkan yang teratur mengkonsumsi kopi hitam dari waktu pagi hari, siang hari, sore hari dan malam hari berjumlah 9 orang. Berdasarkan segmentasi terkait pemakaian, konsumen dikelompokkan berdasarkan keloyalan konsumen, tingkat pemakaian, dan alasan pemilihan produk dibanding produk lain. Berdasarkan keloyalan, konsumen kopi hitam yang loyal 48 orang sedangkan yang tidak loyal 12 orang. Berdasarkan tingkatmengkonsumsi kopi hitam,konsumen yang tergolongpenikmatringan 17 orang, penikmat sedang 24 orang dan penikmat berat 19 orang dari 60 responden sebagai subjek penelitian. Alasan konsumen memilih kopi hitam dibanding produk sejenis lain karena rasa kopi hitam yang khas dengan rasa yang sesuai dengan keinginan konsumen. Berdasarkan Segmentasi psikografis, mengelompokkan konsumen berdasarkan kegiatan konsumen, sikap konsumen, pendapat konsumen dan bagaimana 
konsumen kopi hitam menghabiskan waktu. Konsumen kopi hitam yang suka menghabiskan waktu dengan membaca surat kabar berjumlah 46 orang sedangkan yang tidak suka membaca surat kabar 14 orang. Konsumen yang suka menonton acara khusus di TV 45 orang yang tidak suka 17 orang. Konsumen yang sukamendengarkan radio, 35 orang sedangkan yang tidaksuka 25 orang.Secarakeseluruhankonsumen yangberpendapattidakadaperubahan rasa pada kopi hitam dari dahulu sampai sekarang.

Berdasarkan Segmentasi psikologis konsumen dikelompokkan berdasarkan motivasi, kepribadian, dan pengetahuan. Berdasarkan motivasi, konsumen yang menikmati kopi hitam karena interaksi sosial sebanyak 54 orang, sedangkan karena dorongan dari teman 6 orang. Konsumen yang suka dengan produk yang berkualitas 58 orang yang tidak suka produk yang berkualitas 2 orang. Konsumen yang suka mencoba produk baru sejenis 47 orang yang tidak suka produk baru sejenis 13 orang. Konsumen yang aktif mengikuti perkembangan ekonomi dan politik sebanyak 55 orang sedangkan yang tidakaktif mengikuti perkembangan 5 orang.

\section{DAFTAR PUSTAKA}

Azhari, dkk., Dasar-dasar Ekonomi Islam,Bandung: Cita pustaka Media, 2006.

Abdul Rivai Darsono Prawironegoro, Manajemen Strategis, Jakarta: Mitra Wacana Media, 2015.

Burhan Bungin, Analisis Data Penelitian Kualitatif, Jakarta: PT Raja GrafindoPersada, 2003.

Danang Sunyoto, Praktik Riset Perilaku Konsumen, Yogyakarta: CAPS Center of Academic Publishing Service, 2014.

Ernie Tisnawati Sule \& Kurniawan Saefullah, Pengantar Manajemen, Jakarta: Kencana, 2010.

Fandy Tjiptono, Strategi Pemasaran, Yogyakarta: Andi Yogyakarta, 2015. 
Hasibuan, Abdul Nasser, Effects of Auditor Quality on Market-besed and Accounting-based Financial Statement Quality and Its Impacts on Economic Consequences (A Case Indonesian Capital Market), Internasional Journal of Economic Research No.14 (2017).

Lexy J. Meleong, Metodologi Penelitian Kualitatif, Bandung: PT Remaja Rosdakarya, 2000.

Leon G. Schiffman\& Leslie Lazar Kanuk, Perilaku Konsumen Jakarta: PT Indeks, 2000.

Mahmud Machfoez, Pengantar Bisnis Modern, Yogyakarta: Andi Yogyakarta, 2007.

Muda, Iskandar dan Abdul Nasser Hasibuan, Public Discovery of The Concept of Money with Value of Time Emerald Reach Proceeding Series (Proceeding of MICoMS 2017), Vol 1 pp.255-261.

Mudrajad Kuncoro, Metode Riset untuk Bisnis \& Ekonomi, Jakarta: Erlangga, 2009.

Mulyadi Nitisusastro, Perilaku Konsumen, Bandung: Alfabeta, 2013.

Muhammad Idris, "Digemari Kaum Milenial, Konsumsi Kopi RI Tumbuh 8\% per Tahun" https://m.detik.com, diakses 28 Juni 2018 pukul 11:42 AM.

P3EI (Pusat Pengkajian dan Pengembangan Ekonomi Islam Universitas Islam Indonesia Yogyakarta atas Kerja Sama dengan Bank Indonesia), Ekonomi Islam,Jakarta: PT Raja Grafindo Persada, 2013.

Philip Kotler \& Kevin Lane Keller, Manajemen Pemasaran, Jakarta: PT Indeks, 2006

Philip Kotler \& A.B. Susanto, Manajemen Pemasaran di Indonesia, Jakarta; Salemba Empat, 2000. 
Rosadi Ruslan, Metode Penelitian Public Relation dan Komunikasi, Jakarta: Rajawali Pers 2010.

Sugiyono, Metode PenelitianBisnis, Bandung: Alfabeta, 1999, Metode Penelitian Kuantitatif Kualitatif dan R \& D, Bandung: Alfabeta, 2011.

Ujang Sumarwan, Perilaku Konsumen, Bogor: Ghalia Indonesia, 2011.

Wawancara langsung dengan Bapak M. Yunus Hutasuhut dilakukan pada hari Jum'at 21 April 2017 di Industri Pengolahan Kopi Hitam.

Wawancara tidak langsung dengan Bapak M. Yunus Hutasuhut menggunakan media sosial Whatsapp dilakukan pada hari Selasa 30 Januari 2018.

Wawancara dengan konsumen kopi hitam dilakukan pada hari Sabtu 21 April 2018. 